\title{
The Influence of Papaya Leaf Extract to Anthracnose Disease in Papaya Fruit
}

\author{
Sudiono ${ }^{1^{*}}$, Efri $^{2}$ and Muhammad Asep Awaludin ${ }^{1}$ \\ ${ }^{1}$ Department of Agrotechnology, Faculty of Agriculture, Lampung University, Postal Code 35144, \\ Bandar Lampung, Indonesia. \\ ${ }^{2}$ Department of Protection, Faculty of Agriculture, Lampung University, Postal Code 35144, \\ Bandar Lampung, Indonesia.
}

\section{Authors' contributions}

This work was carried out in collaboration among all authors. Authors Sudiono and EY designed the study and wrote protocol. Author MAA performed statistical analysis and made some literature searches. Author Sudiono wrote the first draft of manuscript and managed the analyses of the study. All authors read, contributed and approved the final version of the manuscript.

Article Information

DOI: $10.9734 / A R R B / 2019 / v 34 i 330152$ Editor(s):

(1) Paola Angelini, Department of Applied Biology, University of Perugia, Perugia, Italy. Reviewers:

(1) Zlatin Zlatev, Trakia University, Bulgaria (2) Douira Allal, University Ibn Tofail, Morocco. (3) Sibdas Baskey, Uttar Banga Krishi Viswavidyalaya, Kalimpong, India. Complete Peer review History: http://www.sdiarticle4.com/review-history/54157

Original Research Article

Received 20 November 2019

Accepted 24 January 2020

Published 30 January 2020

\begin{abstract}
Aims: The objective of this research was to find out the influence of papaya leaf extract to the invitro growth of Colletotrichum gloeosporioides and in-vivo anthracnose disease occurrence at papaya fruit.

Methodology: This research used completely randomized design with seven treatments and four replications. Obtained data were analyzed by using analysis of variance and mean scores were compared and tested with least significance difference (LSD) at $5 \%$ and polynomial test at $5 \%$.

Results: The research result showed the significant influence of papaya leaf extract and synthetic fungicide in inhibiting the growth of Colletotrichum gloeosporioides colony and the disease occurrence at papaya fruit. The polynomial test result of papaya leaf extract showed linier pattern of C. Gloeosporioides colony diameter and disease course progression.

Conclusion: The papaya leaf extract inhibited C. Gloeosporioides colony growth at 2 up to 7 days after inoculation, but it did not inhibit spore germination and its density. The papaya leaf extract also inhibit the disease occurrence at 5 and 6 days after application.
\end{abstract}


Keywords: Colletotrichum gloeosporioides; vegetative fungicide; disease occurrence; papaya.

\section{INTRODUCTION}

Papaya (Carica papaya L.) is a common fruit plant in Indonesia and its fruit has rich nutrition. Papaya fruit contains of enzymes, vitamin A, B, $\mathrm{C}, \mathrm{E}$, minerals, chymopapain and protease III enzymes [1,2]. Papaya fruit domestic and export demands are increasing annually, but in fact, the papaya fruit production in Indonesia decreases. Papaya production in Indonesia was 904,284 tons in 2016 [3], and it decreased into 875,112 tons in 2017 [4]. This production decrease was caused by fruit damage from improper postharvesting handling or because of pest organism attack such as pathogenic fungi [5].

One of pathogenic fungi is Colletotrichum gloeosporioides that causes anthracnose disease at papaya fruit. Anthracnose disease causes low papaya fruit quality and it is considered as post-harvesting fruit disease, but the pathogen can also infect the plant at preharvesting stage. This pathogenic fungi causes red-brownish, wet, small sized, and rounded spots at fruits near to ripening period. At ripen fruit, these spots grow wider quickly to form rounded, red-brownish, and a little bit depositing spots. Then, this pathogenic fungi will continue to grow and rotten inside part of the fruit so that fruit tissues go rotten, softening, and dark coloring $[6,7]$.

Farmers commonly control anthracnose disease by using synthetic fungicide. Continuous fungicide use will increase cost production, farmers' health risks, and deteriorate environment. Considering the bad effects of synthetic fungicide, a more secure alternative for health and environment needs to make. Using vegetative fungicide from vegetative extracts shall be an alternative to overcome anthracnose disease more safely and environmentally friendly [8].

Papaya leaf extract potential can be used as vegetative fungicide to replace synthetic fungicide. The objective of this research was to find out the influence of papaya leaf extract to the in-vitro growth of Colletotrichum gloeosporioides and in-vivo anthracnose disease occurrence at papaya fruit (Carica papaya L.).

\section{MATERIALS AND METHODS}

This research used completely randomized design with seven treatments and four replications. They were Antracol $70 \mathrm{WP}$ with pronipep $70 \%$ active material as synthetic fungicide (P1), control without fungicide (P2), $10 \%$ concentrated papaya leaf extract (P3), $20 \%$ concentrated papaya leaf extract (P4), 30\% concentrated papaya leaf extract (P5), 40\% concentrated papaya leaf extract (P6), and 50\% concentrated papaya leaf extract (P7). Each treatment was done in duplo (2 sets). This research was conducted in two stages; testing inhibition ability of papaya extract leaf to C. gloeosporioides growth in-vitro and testing papaya leaf extract in-vivo to intensity of anthracnose disease in papaya fruit. Obtained data were analyzed with analysis of variance and then mean scores were compared and tested with least significant difference (LSD) test at 5\% level and polynomial test at $5 \%$ level. In-vitro observation parameters were diameter of $C$. gloeosporioides colony, C. gloeosporioides spore density, C. gloeosporioides spore germination.

The colony diameter estimation was done with the following formula:

$\mathrm{D}=\frac{\mathrm{D} 1+\mathrm{D} 2+\mathrm{D} 3+\mathrm{D} 4}{4} \times 100 \%$

Description:

$\mathrm{D}=\mathrm{C}$. Gloeosporioidescolony diameter $(\mathrm{cm})$

D1, D2, D3, D4= C. Gloeosporioides colony length $(\mathrm{cm})$ as results of four different directions.

C. Gloeosporioides spore density can be estimated by using the following formula [9]:

$C=\frac{t}{n} \times 0.25 \times 10^{6}$

Description

$\mathrm{C}=$ Spore density $/ \mathrm{ml}$ of C. gloeosporioides suspension

$\mathrm{t}=$ spore total amount in observed sample box $\mathrm{n}=$ sample box numbers ( 5 middle sized boxes) $0.25=$ Correction factor of middle scaled sample box use at haemacytometer

Spore germination can be estimated by using the following formula:

Spore germination $=\frac{\text { Numbers of germinated spore }}{\text { Numbers of not germinated spore }} \times 100 \%$

In-vivo observation parameter was the anthracnose disease occurrence at papaya fruit. 
The disease occurrence can be estimated by using the following formula [10]:

Occurence $=\frac{\text { Numbers of spots showing symptoms }}{\text { Nummbers of observed spots (sample) }} \times 100 \%$

\section{RESULTS AND DISCUSSION}

\subsection{The Influence of Papaya Leaf Extract to C. Gloeosporioides Growth}

The analysis of variance of papaya leaf extract and synthetic fungicide to $C$. gloeosporioides colony growth shows a significant influence in inhibiting the colony growth (Table 1). Papaya leaf extract and synthetic fungicide inhibit the $C$. gloeosporioides colony at 2 up to 7 days after inoculation (dai). At 8 up to 10 days after inoculation, the papaya leaf extract does not influence significantly in inhibiting $C$. gloeosporioides colony growth.

The least significant difference (LSD) test of papaya leaf extract treatment at $10 \%$ concentration shows significant difference in inhibiting C. gloeosporioides colony growth compared to control without fungicide at 2 up to 4 days after inoculation. $20 \%, 30 \%, 40 \%$, and $50 \%$ concentrations of papaya leaf treatments show different significances in inhibiting $C$. gloeosporioides colony growth in 2 up to 7 days after inoculation compared to control without fungicide. In addition, the synthetic fungicide with propineb $70 \%$ active material shows significant difference in inhibiting the C. gloeosporioides colony growth compared to control without fungicide in 2 up to 7 days after inoculation. Based on this finding, the abilities of papaya leaf extract at $20 \%, 30 \%, \quad 40 \%$, and $40 \%$ concentrations in inhibiting C. gloeosporioides colony growth are the same with the control ability of synthetic fungicide with propined $70 \%$ active material.

The papaya leaf extract and synthetic fungicide have inhibiting ability to $C$. gloeosporioides colony growth compared to control without fungicide (Fig. 1). 50\% concentration of papaya leaf extract (P7), that has been the best concentration, has strongest inhibiting ability to the C. gloeosporioides colony growth compared to other papaya leaf extract concentrations.

The polynomial test result of papaya leaf extract concentrations to $C$. gloeosporioides colony growth shows a linier pattern, and it is presented with equation of $(Y=-0,1857 x+23,476)$. This result shows that the higher is the papaya leaf extract concentration, then the stronger is the inhibiting ability to C. gloeosporioides colony growth (Fig. 2).

The observation results of the influence of papaya leaf extract and synthetic fungicide to spore density are presented in Table 2, and the spore germination results after 14 hours are presented in Table 3 . The analysis of variance to the influence of papaya leaf extract and synthetic fungicide to spore density and germination show no significant influence in inhibiting the progress of spore density and germination. This indicates that papaya leaf extract and synthetic fungicide with propineb $70 \%$ active material is unable to inhibit C. gloeosporioides spore density and germination.

Table 1. Effect of papaya leaf extract and synthetic fungicide to C. gloeosporioides colony growth

\begin{tabular}{llllllllll}
\hline Treatment & \multicolumn{70}{c}{ Diameter average $\mathbf{( c m )}$} \\
\cline { 2 - 10 } & 2 dai & $\mathbf{3}$ dai & 4 dai & $\mathbf{5 ~ d a i}$ & $\mathbf{6}$ dai & $\mathbf{7 ~ d a i}$ & $\mathbf{8}$ dai & $\mathbf{9}$ dai & $\mathbf{1 0}$ dai \\
\hline P1 & $0,500 \mathrm{a}$ & $0,738 \mathrm{a}$ & $1,200 \mathrm{a}$ & $1,819 \mathrm{a}$ & $2,394 \mathrm{a}$ & $3,094 \mathrm{a}$ & 3,731 & 4,238 & 4,600 \\
P2 & $1,038 \mathrm{~b}$ & $1,988 \mathrm{~b}$ & $3,138 \mathrm{~b}$ & $4,250 \mathrm{~b}$ & $5,369 \mathrm{c}$ & $6,656 \mathrm{c}$ & 7,794 & 8,531 & 8,900 \\
P3 & $0,638 \mathrm{a}$ & $1,225 \mathrm{a}$ & $2,063 \mathrm{a}$ & $3,100 \mathrm{ab}$ & $3,981 \mathrm{bc}$ & $5,094 \mathrm{bc}$ & 6,013 & 7,013 & 7,919 \\
P4 & $0,500 \mathrm{a}$ & $0,806 \mathrm{a}$ & $1,788 \mathrm{a}$ & $2,669 \mathrm{a}$ & $3,575 \mathrm{ab}$ & $4,663 \mathrm{ab}$ & 5,694 & 6,700 & 7,700 \\
P5 & $0,544 \mathrm{a}$ & $0,944 \mathrm{a}$ & $1,731 \mathrm{a}$ & $2,663 \mathrm{a}$ & $3,375 \mathrm{ab}$ & $4,319 \mathrm{ab}$ & 5,269 & 6,181 & 7,219 \\
P6 & $0,531 \mathrm{a}$ & $0,800 \mathrm{a}$ & $1,475 \mathrm{a}$ & $2,281 \mathrm{a}$ & $3,319 \mathrm{ab}$ & $4,431 \mathrm{ab}$ & 5,519 & 6,650 & 7,625 \\
P7 & $0,500 \mathrm{a}$ & $0,681 \mathrm{a}$ & $1,394 \mathrm{a}$ & $2,225 \mathrm{a}$ & $2,969 \mathrm{ab}$ & $3,888 \mathrm{ab}$ & 4,744 & 5,650 & 6,531 \\
$\mathrm{~F}_{\text {count }}$ & 6,586 & 4,614 & 3,354 & 3,093 & 3,123 & 2,781 & 2,486 & 2,192 & 2,041 \\
$\mathrm{~F}_{\text {table }}$ & 2,573 & 2,573 & 2,573 & 2,573 & 2,573 & 2,573 & 2,573 & 2,573 & 2,573 \\
Conclusion & $*$ & $*$ & $*$ & $*$ & $*$ & $*$ & NS & NS & NS \\
LSD 5\% & 0,225 & 0,630 & 1,034 & 1,320 & 1,557 & 1,953 & - & - & - \\
\hline
\end{tabular}

Description: $P 1=$ Synthetic fungicide; $N S=$ Not Significant; $P 2=$ Control without fungicide $;{ }^{*}=$ Significant $P 3=10 \%$ papaya leaf extract; dai: days after inoculation; $P 4=20 \%$ papaya leaf extract; $P 5=30 \%$ papaya leaf extract; $P 6=40 \%$ papaya leaf extract; $P 7=50 \%$ papaya leaf extract 
Table 2. The influence of papaya leaf extract and synthetic fungicide treatments to spore density

\begin{tabular}{ll}
\hline Treatment & Spore density/mI \\
\hline Control with synthetic fungicide & 87.500 \\
Control without fungicide & 900.000 \\
$10 \%$ papaya leaf extract & 275.000 \\
$20 \%$ papaya leaf extract & 212.500 \\
$30 \%$ papaya leaf extract & 162.500 \\
$40 \%$ papaya leaf extract & 300.000 \\
$50 \%$ papaya leaf extract & 925.000 \\
$\mathrm{~F}_{\text {count }}$ & $2.437 \mathrm{NS}$ \\
$\mathrm{F}_{\text {table }}$ & 2.573 \\
\hline & Description: ${ }^{*}=$ Significant $N S=$ Not Significant
\end{tabular}

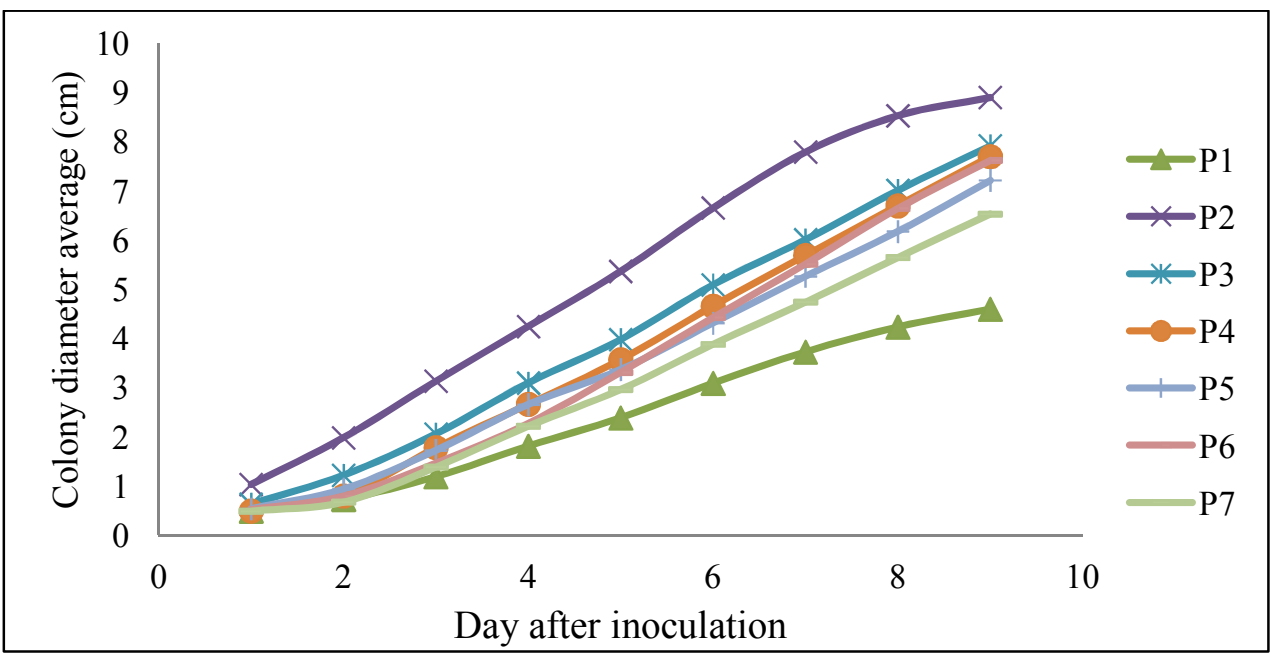

Fig. 1. Effect of papaya leaf extract and synthetic fungicide influences to C. gloeosporioides colony growth at 2 up to 10 days after inoculation

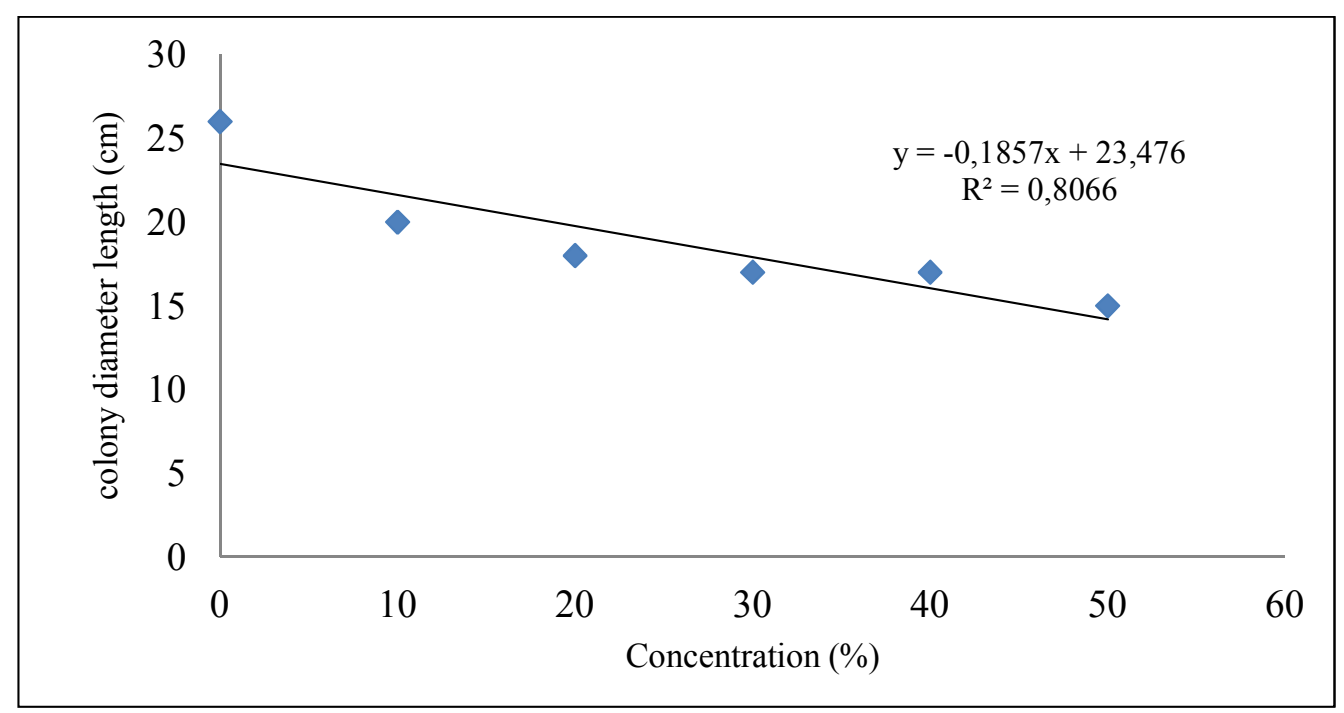

Fig. 2. Growth C. gloeosporioides on certain concentrations of papaya leaf extract after 7 days of inoculation 
Table 3. The influence of papaya leaf extract and synthetic fungicide to spore germination after 14 hours

\begin{tabular}{ll}
\hline Treatment & $\begin{array}{l}\text { Spore } \\
\text { germination (\%) }\end{array}$ \\
\hline $\begin{array}{l}\text { Control with synthetic } \\
\text { fungicide }\end{array}$ & 91.50 \\
Control without & 79.00 \\
fungicide & \\
10\% papaya leaf extract & 83.75 \\
$20 \%$ papaya leaf extract & 93.75 \\
$30 \%$ papaya leaf extract & 95.00 \\
$40 \%$ papaya leaf extract & 44.50 \\
$50 \%$ papaya leaf extract & 90.00 \\
$\mathrm{~F}_{\text {count }}$ & $2.474 \mathrm{NS}$ \\
$\mathrm{F}_{\text {table }}$ & 2.573 \\
\hline \multicolumn{2}{c}{ Description: ${ }^{*}=$ Significant $N S=$ Not Significant }
\end{tabular}

The in-vitro testing result shows that the papaya leaf extract inhibits C. gloeosporioides colony growth at 2 to 7 days after inoculation. This is assumed because there is an active compound in young papaya leaf such as papain and alkaloid. Papaid is a protease enzyme that decomposes proteins [11]. Decomposed proteins will cause protein denaturation so that the fungal protein is damaged and the fungal growth is inhibited. Alkaloid is antifungal compound that is able to inhibit nucleic acid biosynthesis [12]. Inhibited nucleic acid biosynthesis will disturb protein composition process so that fungal growth will be disturbed. However, papaya leaf extract does not inhibit spore density and germination. It is assumed that the active compound in the papaya leaf extract is unable to inhibit C. gloeosporioides at generative phase. This finding shows that the papaya leaf extract has fungi-static characteristic (inhibiting fungal growth).

\subsection{The Influence of Papaya Leaf Extract to Anthracnose Disease Occurrence in Papaya Fruit}

Testing papaya leaf extract influence to anthracnose disease occurrence in papaya fruit was done by using the best papaya leaf extract treatment from in-vitro testing results. The in-vitro test result obtained four treatments with $20 \%$, $30 \%, 40 \%$ and $50 \%$ concentrations. Based this finding, the anthracnose disease occurrence at papaya fruit was done by using six treatments. They were P1 (control with synthetic fungicide), P2 (control without fungicide), P4 (10\% papaya leaf extract), P5 (30\% papaya leaf extract), P6 (40\% papaya leaf extract), and $\mathrm{P} 7$ (50\% papaya leaf extract).
The analysis of variance result of the influence of papaya leaf extract and synthetic fungicide to anthracnose disease occurrence at papaya fruit showed that there was a significant influence in inhibiting anthracnose disease at 5 and 6 days after application (Table 4). Meanwhile, at 4, 7, and 8 days after application the papaya leaf extract and synthetic fungicide did not influence significantly in inhibiting the anthracnose disease occurrence in papaya fruit.

The least significant difference (LSD) test showed that the $30 \%$ and $50 \%$ papaya leaf extract concentrations and synthetic showed significant difference in inhibiting anthracnose disease occurrence at papaya fruit compared to control without fungicide at 7 days after application. At 6 days after application, only $30 \%$ papaya leaf extract concentration that showed significant difference in inhibiting the anthracnose disease compared to control without fungicide. These findings showed that the abilities of $30 \%$ and $50 \%$ papaya leaf extract concentrations in inhibiting anthracnose disease at papaya fruit was the same with control with synthetic fungicide with propineb $70 \%$ at 5 days after application. At 6 days after application, only 30\% papaya leaf extract concentration that was able to inhibit the anthracnose disease at papaya fruit.

In-vivo testing result showed that papaya extract leaf inhibited anthracnose disease intensity, occurrence, and development at papaya fruit, and even it had the same effectiveness with synthetic fungicide with propineb $70 \%$ active material. However, the papaya leaf extract and synthetic fungicide did not show significant influence to papaya fruit disease severity. The research result showed that $5 \%$ papaya leaf extract concentration and female sex were the best extract to suppress anthracnose disease in red chili fruit compared to other papaya leaf extract concentrations and other papaya leaf extract types. In addition, used papaya leaf extract as vegetative fungicide to control Colletotrichum sp. fungi that caused anthracnose disease at chili (Capsicum annuum L.), and the research result showed that papaya leaf extract was able to slow down symptoms in chili fruit [13].

The similar research result was obtained that used papaya leaf extract to slow down the Alternaria solani fungal mycelium at sweet potato. The research result showed that the higher was the papaya leaf extract concentration, then the strongest will be the 
Table 4. The influence of papaya leaf extract and synthetic fungicide to anthracnose disease in papaya fruit

\begin{tabular}{|c|c|c|c|c|c|}
\hline \multirow[t]{2}{*}{ Treatment } & \multicolumn{5}{|c|}{ Disease occurrence average (\%) } \\
\hline & 4 daa & 5 daa & 6 daa & 7 daa & 8 daa \\
\hline $\mathrm{P} 1$ & 0 & $12.5 \mathrm{a}$ & $65 a b$ & 85 & 92.5 \\
\hline P2 & 25 & $62.5 \mathrm{~b}$ & $82.5 \mathrm{~b}$ & 95 & 95 \\
\hline P4 & 22.5 & $42.5 \mathrm{ab}$ & $65 a b$ & 75 & 82.5 \\
\hline P5 & 0 & $12.5 \mathrm{a}$ & $22.5 \mathrm{a}$ & 55 & 85 \\
\hline P6 & 22.5 & $60 a b$ & $90 a b$ & 95 & 95 \\
\hline P7 & 10 & $22.5 \mathrm{a}$ & $57.5 \mathrm{ab}$ & 80 & 90 \\
\hline $\mathrm{F}_{\text {count }}$ & 1.171 & 3.241 & 2.819 & 1.251 & 0.350 \\
\hline $\mathrm{F}_{\text {table }}$ & 2.773 & 2.773 & 2.773 & 2.773 & 2.773 \\
\hline Conclusion & NS & * & * & NS & NS \\
\hline LSD 0.05 & - & 3.767 & 4.176 & - & - \\
\hline
\end{tabular}

inhibiting ability to Alternaria solani fungal mycelium growth. This research showed that the papaya leaf extract has the same effectiveness with synthetic fungicide. Papaya leaf extract and synthetic fungicide are effective in inhibiting $C$. gloeosporioides fungal colony growth, disease occurrence, and anthracnose disease progress at papaya fruit. These findings show that papaya leaf extract can be used as an alternative to control anthracnose disease at papaya fruit compared to synthetic fungicide with propineb $70 \%$ active material.

\section{CONCLUSION}

The papaya leaf extract inhibits $C$. gloeosporioides fungal colony growth at 2 up to 7 days after inoculation, but it does not inhibit spore density and germination. The papaya leaf extract also inhibits anthracnose disease occurrence at papaya fruit in 5 and 6 days after application.

\section{ACKNOWLEDGEMENT}

The authors would like to thank Dean of Agricultural Faculty University of Lampung for funding to research.

\section{COMPETING INTERESTS}

Authors have declared that no competing interests exist.

\section{REFERENCES}

1. Kharisma Y. Tinjauan pemanfaatan tanaman pepaya dalam kesehatan. Fakultas Kedokteran Universitas Islam Bandung. Bandung; 2017.
2. Muss Clauss, Mosgoeller W, Endler Thomas. Papaya preparation (Caricol) in digestive disorders. Neuroendocri-nology Letters. 2013;34(1):38-46.

3. Badan Pusat Statistik (BPS). Statistik Tanaman Buah-buahan dan Sayuran Tahunan Indonesia; 2016.

Available:http://www.bps.Go.ld (Accessed 30 July 2019)

4. Badan Pusat Statistik (BPS). Statistik Tanaman Buah-buahan dan Sayuran Tahunan Indonesia; 2017. Available:http://www.bps.go.id (Accessed 30 July 2019)

5. Apriyadi AR, Wahyuni WS, Supartini V. Pengendalian penyakit patik (Cercospora nicotianae) pada tembakau na oogst secara in-vivo dengan ekstrak daun gulma kipahit (Tithonia diversifolia). Berkala Ilmiah Pertanian. 2013;1(2):30-32.

6. Semangun H. Penyaki-penyakit Tanaman Hortikultura di Indonesia. Gadjah Mada University Press. Yoyakarta. 845 hlm; 2007.

7. Kusumaningtyas EL, Sukmawati, Astuti E. Penentuan golongan bercak senyawa aktif dari ekstrak n-heksan Alpina galangal terhadap Candida albicans dengan bioautografi dan kromatografi lapis tipis. Jurnal IImu Ternak dan Veteriner. 2008;13(4):323-328.

8. Septiana W, Efri, Aeny TN, Pengaruh berbagai tingkat fraksi ekstrak buah mengkudu ( $M$. citrifolia) terhadap $C$. capsici pada cabai (C. anum L.) secara invitro. Jurnal Agrotek Topika. 2013;1(2): 202-207. 
9. Gabriel BP, Riyanto. Metarhizium anisopliae Taksonomi, Patologi, Produksi dan Aplikasinya. Proyek Pengembangan Perlindungan Tanaman Perkebunan. Direktorat Perlindungan Tanaman Perkebunan. Dapertemen Pertanian. Jakarta. 25 hlm; 1989.

10. Ginting C. Ilmu Penyakit Tumbuhan (Konsep dan Aplikasi). Lembaga Penelitian Universitas Lampung. Bandar Lampung. 2013;1-203.

11. Yulianty, Lande ML, Handayani TT. Effectiveness of Carica papaya leaves extract in controlling anthracnose diseases caused by Colletotrichum sp. on red chilli
(Capsicum annuum L.). Jurnal Mikologi Indonesia. 2018;2(1):49-55.

12. Suryadi Y, Tri Puji Priyatno TP, Samudra IM, Susilowati D, Sriharyani TS, Syaefudin. Pengendalian Penyakit Antraknosa Colletotrichum gloeosporioides) menggunakan Kitosan Nano Hasil Hidrolisis Kitinase Asal Burkholderia cepacia Isolat E76. Jurnal Agro Biogen. 2012;13(2):111-1.

13. Suleiman MN. Fungitoxic activity of neem and pawpaw leaves extracts on Alternaria solani, causal organism of yam rots. Advances in Environmental Biology. 2010;4(2):159-161.

(c) 2019 Sudiono et al.; This is an Open Access article distributed under the terms of the Creative Commons Attribution License (http://creativecommons.org/licenses/by/4.0), which permits unrestricted use, distribution, and reproduction in any medium, provided the original work is properly cited.

Peer-review history:

The peer review history for this paper can be accessed here: http://www.sdiarticle4.com/review-history/54157 